\title{
1. Overview of the company law regime in China
}

\subsection{WHY STUDY CHINESE COMPANY LAW?}

The development of company law in China is increasingly catching the eye of international investors, practitioners, and academics and government officials who are China observers. The study of Chinese company law is moving towards the forefront of international scrutiny for a number of reasons. First, companies (or 'corporations') ${ }^{1}$ are the dominant players in China's rapidly growing economy. Business entities with the nature of modern companies did not exist in China during the first few decades of the Peoples' Republic ('PRC'), as it then practiced a planned economy in which all economic entities were run directly either by the state or collectives. ${ }^{2}$ However, after years of economic reform, the company limited by shares is now the dominant form of business organization. According to official statistics, by the first half of 2005, there were about 1.2 million enterprises in the People's Republic of China ('China' or the 'PRC') ${ }^{3}$ registered in the form of companies legally established under the national Company Law. ${ }^{4}$ Companies are overwhelmingly predominant in China's major economic sectors. The enterprise companies, themselves a result of an economic revolution that is

1 'Company' and 'corporation' are used interchangeably in this book. Company law, when referring not specifically to the national Company Law, is also used interchangeably with corporate law.

2 Naughton (2007) (noting in the command economic system in China between 1949 and 1978 the government owned all large factories and other enterprises, and, in rural areas, agricultural collectives owned farming lands). It should, however, be pointed out that Western-style companies existed in the first decade of the PRC until they were all eliminated by 1957. See Dong (2001), pp. 174-97.

3 Depending on the context, China is also frequently used to refer to the pre-PRC Chinese nation in this book.

4 An Jian (2005), p. 1. The currently enforceable company law in China is the Company Law of the People's Republic of China amended in 2005 (hereinafter the PRC Company Law, or Company Law 2005, or the 'new 
ongoing in China, are making the most significant contribution to the dynamism of the Chinese economy. It is not exaggerated to say that the fate of enterprise reform will determine the future of the Chinese economy, namely whether China will successfully complete its transformation from a planned to a market-based economy, and in this process, improve the long-term competitiveness of its industries. In this cause, China's companies and securities laws will play the central role of defining enterprises as legally independent and responsible market participants, encouraging corporatization of state-owned enterprises, and providing a national legal basis for the establishment, governance, and transaction activities of business enterprises registered as companies. ${ }^{5}$

Chinese company law finds further importance through its expanding coverage of foreign-invested enterprises (FIEs). As discussed in more detail in section 1.3 below, China is phasing out its dualist regime, which subjected domestic business organizations and FIEs to different regulatory frameworks. Subject to certain exceptions, FIEs are now governed by the Company Law under the doctrine of general law-special law relationship, which connotes that the FIE laws, as long as they concern registered companies, are special laws in relation to the Company Law. Indeed, the Organisation for Economic Co-operation and Development (OECD) has suggested that, "[t]he Chinese government may wish to consider a possible evolution towards the integration of FDI law into domestic company law so that FIEs are eventually treated on a par with domestic enterprises'. 6

As Chinese companies are rapidly expanding overseas and seeking listing in foreign stock exchanges, even those persons who have never set foot in China could be affected by (the positive and negative aspects of) Chinese company law if they purchase shares of a Chinese company. Thus, the Vice Chairman of the U.S.-China Economic and Security Review Commission (USCC) remarked, quite negatively, about the impact of Chinese companies going overseas:

Company Law'). The evolution of the PRC Company Law will be discussed in later sections.

$5 \quad$ See e.g. OECD (2000), p. 433 (stating 'The current Company Law [1993] constitutes the legal basis for the drive to establish SOEs as separate legal entities through corporatisation. For China, corporatisation was a continuation of past gradual reforms and a new means to increase SOE autonomy while maintaining oversight by the State. The assumption is that corporatised SOEs would behave like privately-owned corporates in an advanced market economy, even though they constitute to be owned by the State'.

6 OECD (2003), p. 59. 
The vast majority of U.S.-listed Chinese enterprises - 92 percent - are owned and operated by the Chinese state. Questionable corporate governance, accounting practices, and minority shareholder rights make this a subject of particular concern to Congress. These issues have significant implications for U.S. investors looking to purchase stock in Chinese firms, as well as financial analysts tasked with unraveling Chinese companies' complex web of relationships and finances. These facts raise questions abut the suitability of Chinese debt and equity listings in the U.S. markets, and so-called 'China funds' mutual funds focused on investing in China securities. I am concerned that U.S. investors may not have sufficient information to make informed decisions about the risk of these investments ... ${ }^{7}$

From a theoretical perspective, Chinese company law is also worthy of study because it poses conceptual challenges to the conventional wisdom of corporate law; this will be further discussed in section 1.3.

\subsection{A SHORT HISTORY OF CHINA'S COMPANY LAW ${ }^{8}$}

Company Law, in the form of a national code, existed before the People's Republic of China was established. The Qing Dynasty enacted China's first Company Law (Gongsilü) in 1904. As noted by commentators, '[t]he 1904 Company Law, which drew broadly upon both English and Japanese company law models, established a number of different types of companies, created them as juristic persons and introduced the idea of the limited liability company limited by shares' ${ }^{9}$ Enacted in the wake of the Dynasty's demise, the law was barely implemented when, ${ }^{10}$ seven years later, the Qing monarchy was abolished.

7 USCC (2004), p. 8 (Prepared Statement of Vice Chairman C. Richard D'Amato).

8 This section presents a very brief, summarized history of China's corporate law. It is not intended to provide a complete analysis of this historical development, and must completely neglect the interesting social and human factors that this development entailed. A more detailed explanation will be offered in later chapters of this book as opportunity and need for discussion of the historical background of corporate law arises.

9 Tomasic and Fu (1999), p. 136. See also Kirby (1995), pp. 47-8 (noting that this Company Law ran up to 131 articles and established four types of companies, with its central contribution lying in introducing 'the company limited by shares, wherein the liability of shareholders and directors was limited to the value of their shares').

10 Kirby (1995, p. 48) observes that there were 227 companies registered in 1908 , but only 22 of them were of significance size. 
In the Republican period, several company laws were promulgated at different times. A Company Ordinance (Gongsi Tiaoli) replaced the 1904 Qing Company Law in 1914. As William Kirby observes, '[t]he law was much clearer than its predecessor in its basic regulations ... and would serve as the foundation of future revisions of the law', although, 'as in 1904, its effect on the structure of Chinese enterprises would be small' ${ }^{11}$

The Nationalist Government of the Republic of China, the first Republican Government that had more effective control of the almost dismantled country, enacted a new Company Law in 1929. Kirby (1995) notes that the law was given an instrumental task by the government to serve as 'one vehicle in promoting state ascendancy over all private enterprise, Chinese and foreign' ${ }^{12}$ This was, however, in line with the policy and spirit of that government: an important principle of the government's national development policy framework, originally crafted by the new republic's 'State Father' (Guofu), Dr. Sun Yat-Sen, was one of 'restricting private capital' (jiezhi ziben) and promoting state control of the economy. For example, the law significantly suppressed the power of large shareholders by limiting the voting power of any shareholder to less than one-fifth of the votes of all shares, regardless of the percentage of their ownership in the company. ${ }^{13}$ Interestingly enough, the law does not govern state enterprises, which were left to special regulations promulgated later. ${ }^{14}$

The 1929 Company Law was eventually replaced by the New Company Law of 1946. The new law aimed to achieve a compromise between the Chinese government's enthusiasm to develop state capitalism and foreign corporations' desire for a Delaware-like, liberal company code. ${ }^{15}$ The background of the revision was the total abolition of extraterritoriality enjoyed by foreign business then as a reward for China's alliance with the Allied Powers during World War II. The foreign firms, which were

11 Kirby (1995), p. 49.

12 See Kirby (1995), p. 51 (also noting 'the abolition of extraterritoriality and the regulation of private enterprises were part of a larger agenda of state-building' for the Nationalist regime).

13 Kirby (1995), p. 52. It is interesting to note that the European Court of Justice recently chastised a German state for exactly this kind of restriction in its attempt to keep control of Volkswagen AG, so as to protect its local labor force. See Commission of the European Communities v Federal Republic of Germany [2007] C 112/05.

14 Kirby (1995), p. 52. See also Fang 2002, p. 283.

15 Kirby (1995, p. 55) notes that during the making of the 1946 law the U.S. government advised the Chinese government in vain to take Delaware as its model for company law. 
then required to register in China, were not willing to operate under the very restrictive 1929 law, and sought amendment. To this end, a section for 'foreign corporations' was created in the 1946 law for the first time in China's corporate law history. As a result, foreign firms would be treated as Chinese companies once they obtained 'recognition and permission' (renxu) from the Chinese government. ${ }^{16}$ Unlike the 1926 law, this law applied also to state enterprises. After losing the civil war, the Nationalist Government carried this law to Taiwan, where it remains in force today, albeit substantially revised in 1966.

After the People's Republic of China was established in 1949, one of the first decisions of the Communist Government was to abolish the Six Codes (liufa quanshu), which represented the legal system of the Nationalist Government. ${ }^{17}$ Starting from 1950, new regulations were introduced to nationalize and collectivize the economy. As a result, companies, upon their nationalization, directly and immediately lost their corporate nature, becoming non-independent economic units, or danwei, either state- or collectively-owned.

After Chairman Mao's death in 1976, Deng Xiaoping steered the country toward pursuing economic growth rather than promoting class struggle, and this model for growth welcomed foreign investment. A Sino-foreign joint venture law was enacted in 1979 to legalize the establishment of foreign-invested limited liability companies. This law was among the first efforts of the post-Mao government to reintroduce independent business organizations with limited liability, and was followed by a series of laws on foreign investment enterprises.

On the domestic front, localities preceded the central government in making laws to create procedures for the restructuring of traditional enterprises into modern corporations. Shenzhen, one of the Special Economic Zones established in 1980 to try out capitalist policies on socialist soil, was the first local government to enact regulations for a corporatization experiment in $1986 .{ }^{18}$ In the same year, the National People's Congress passed the General Principle of Civil Law, which since then has served the PRC as a mini 'civil code', setting forth conditions for establishing enterprises with legal personality that possess property and are able to bear civil liability independently. This 'civil

16 Wen (2005), p. 125.

17 The Six Codes originally referred to the Constitution, the Civil Code, the Commercial Code, the Civil Procedure Code, the Criminal Code, and the Criminal Procedure Code. Later, it was general usage to refer to these texts as the collective body of statutes of the Republic of China.

18 Walter and Howie (2003), p. 91. 
code' was followed by the extremely controversial 1988 Law on Industrial Enterprises owned by the Whole People (the '1988 Enterprise Law'). ${ }^{19}$ A key principle of this last law was that, at least in theory, it made all state-owned enterprises ('SOEs') 'legal persons with civil responsibility for the property left by the state to their management and with independent budgets'. ${ }^{20}$ Obviously, limited liability re-penetrated into the Chinese legal system.

A nationally unified company law was not promulgated until 1993. However, three sets of regulations released in the prior year deserve special attention, as they laid a foundation for the national law. On 15 May 1992, the State Commission for the Restructuring of the Economic System ('SCRES'), in association with other interested central ministries, issued the Share Enterprise Trial Measures. ${ }^{21}$ Pursuant to the Measures, the SCRES released the Standard Opinion on Companies Limited by Shares (hereinafter the 'CLS Standard Opinion')22 and the Standard Opinion on Limited Liability Companies (hereafter the 'LLC Standard Opinion'). ${ }^{23}$ These two ministerial level decrees, soon to be replaced by a national company law, already set up the general corporate framework in China.

The most significant development in China's system of corporate law, however, remains the National People's Congress 1993 promulgation of the national Company Law (hereinafter the '1993 Company Law'), which took effect on 1 July $1994 . .^{24}$ As Article 1 of that Act states, it was intended to "meet the needs of establishing a modern enterprise system, to standardize the organization and activities of companies, to protect the legitimate rights and interests of companies, shareholders and creditors, to maintain the socio-economic order and to promote the development of the socialist market economy'. Consolidating the rules of the two standard opinions, the 1993 Company Law stipulates two types of companies, prescribes their corporate finance and corporate governance

19 Quanmin Suoyouzhi Gongye Qiyefa.

20 Walter and Howie (2003), p. 92.

21 Gufenzhi Qiye Shidian Banfa, SCRES Document No. 30 (1992).

22 Gufen Youxian Gongsi Guifan Yijian, SCRES Document No. 31 (1992). The Chinese gufen youxian gongsi has been translated as 'company limited by shares' or 'joint-stock company' in the English language literature on Chinese law.

23 Youxian Zeren Gongsi Guifan Yijian, SCRES Document No. 31.

24 Zhonghua Renmin Gongheguo Gongsifa, adopted at the Fifth Meeting of the Standing Committee of the Eighth National People's Congress on 29 December 1993. 
structures, and articulates the responsibilities, rights, and liabilities of shareholders, directors, supervisors, and corporate managers. Although it has been subjected to strong criticism, ${ }^{25}$ one must admit that the 1993 Company Law has, for the first time, established an effective and comprehensive corporate law framework for the PRC and facilitated the development of the Chinese securities market.

The 1993 Company Law has been revised three times since its adoption. The first two revisions occurred in December 1999 and August 2004 and touched only a very few technical aspects of the law. ${ }^{26}$ The third revision, made by the Standing Committee of the National People's Congress on 27 October 2005, almost completely rewrote CL 1993, as only about 24 articles of the 1993 law were left untouched. ${ }^{27}$ For this reason, the revised text is customarily referred to as the new 2005 Company Law (or the 'Company Law') rather than a revision of the 1993 Company Law, as if it is entirely new legislation. The 2005 Law brought many changes and relaxed many restrictions on business incorporation and operation in China, including a reduction of the capital requirement, increases in shareholder and creditor protection, and other improvements in corporate governance, such as an increase in information disclosed, and greater power for shareholders to file lawsuits against directors. These 2005 revisions will be discussed at length in the following chapters.

25 See e.g. Howson (1997), p. 128 (noting, 'In many cases, the Company Law was privately termed a "disaster," a keen expression of conservative compromises or the wholesale avoidance of difficult issues implicit in China's transition from state ownership and the mandated allocation of capital to a "socialist market economy."').

26 The 1999 revision changed only two articles, including one new paragraph under Article 67 requiring the installation of a supervisory board in companies 100 percent owned by the state and another paragraph added to Article 292 authorizing the government to approve a 'second board' to support advanced and high-tech companies. The 2004 revision only deleted a paragraph from Article 131 to remove the approval requirement by the securities regulatory authorities for issuance of company shares at a premium.

27 One commentator, who was also a member of the NPC's company law revision group, remarked that he would call the 2005 revised law the 'New Company Law'. See Wang Yong (2005), p. 166. 


\subsection{STRUCTURE AND SCOPE OF APPLICATION OF THE COMPANY LAW, INCLUDING ITS RELATIONSHIP WITH THE FOREIGN INVESTMENT LAWS}

The Company Law, comprising 13 chapters and 219 articles, does not govern all types of business organization. Rather, it provides rules only for limited liability companies ('LLCs') and joint-stock limited companies (JSLCs), also known as 'companies limited by shares'. The Law does not prohibit other business organizations authorized under other laws from being designated as 'companies' (gongsi). For the two types of registered companies, the Law regulates incorporation and registration, finance, transfer of equity interests, shareholder's rights, qualifications, and duties of corporate directors and officers, mergers, and acquisitions, as well as the operation of foreign corporations in China.

A first look at the business law system in China will lead to the impression that domestically-invested companies and foreign-invested enterprises (FIEs) are subject to different regulatory regimes and rules. Apparently, various laws have been created especially for FIEs, including, but not limited to, Chinese-foreign joint ventures, cooperative projects, and wholly foreign-owned enterprises. What is then the impact of the Company Law on FIEs? It depends on what interest a foreign investor is allowed to acquire in China. Today's legislative scheme offers a broad range of options:

1. equity ownership in a joint venture with limited liability;

2. equity ownership in a wholly foreign-owned limited liability company;

3. equity ownership in a foreign-invested joint-stock company;

4. partnership in a Chinese-foreign cooperative project;

5. Ownership of ' $\mathrm{B}$ ' shares in a listed joint-stock company;

6. ownership of ' $\mathrm{H}$ ' shares of Chinese companies traded on a foreign stock exchange; ${ }^{28}$

7. ownership of a holding company for all subsidiary companies in China;

$28 \mathrm{H}$ shares originally referred to shares of PRC incorporated companies traded on the Hong Kong Stock Exchange. It is now a generic term referring to all the PRC corporate shares traded on overseas stock exchanges, including those in Hong Kong, New York, London, and Singapore. 
8. equity ownership in joint venture or wholly foreign-owned financial institution (with limited liability); and

9. mergers with and acquisitions of all types of PRC companies.

Although various special regulations have been issued on the most common regulatory issues facing foreign investment, it is impossible for those discrete regulations to provide self-contained solutions to all the problems. In this sense, the Company Law supplements the FIE laws and regulations. This is made clear by Article 218 of the new Company Law, which reads:

This law shall apply to foreign-invested limited liability companies and joint-stock companies. Where laws on foreign investment provide otherwise, such provisions shall apply. ${ }^{29}$

Evidently, the national Company Law applies to foreign investors and FIEs only when the special legislation on foreign investment is silent on a particular issue. Furthermore, in cases where the FIEs laws differ from provisions of the Company Law, the former prevail. ${ }^{30}$

China appears to be moving toward granting national treatment to FIEs and foreign investors, which would likely close the difference between the Company Law and the FIE laws. In 2007, the National People's Congress passed the Corporate Income Tax Law, unifying the different tax treatments for domestic and foreign-invested companies. Under this Law, FIEs soon will lose the preferential tax treatment they currently receive from the Chinese government.

29 Article 18 of the 1993 Company Law is similar to Article 218 of the 2005 Company Law. For a judicial decision on the applicability of the Company Law to FIEs see infra, Chapter 3, \$3.12.1.

$30 \mathrm{CCH}$ (2005), I26-110. It is worth noting that the Chinese securities regulation is also a dualist regulatory system, as noted in Wang Jiangyu (2004, p. 18):

[A]lthough it is not explicitly established in the relevant laws, the dualist nature of the Chinese securities regulatory framework shall be understood as such, namely that regulations on foreign investment in China's stock market serve as 'special' laws to the general framework, whose provisions shall take precedent to relevant provisions of the general laws in cases in which there is overlap or conflict. For matters not stipulated in foreign investment-specific laws, the provisions of general laws (such as the Securities Law or the Takeover Measures) shall be followed. 


\subsection{SOURCES AND APPLICATION OF CHINA'S COMPANY LAW}

\subsubsection{The Primacy of Legislation in China}

As Keller notes, '[a] person cannot live in China long without becoming aware of the complex, interwoven web of social rules which governs every aspect of Chinese life'. ${ }^{31}$ This also applies to the regulation of companies in China. Needless to say, in China there is always a disparity between the law on paper and the law in practice. This interesting topic, however, is beyond the scope of this book. Here I seek to clarify the 'hierarchy of legal norms and the delineation of law-making powers' 32 with respect to companies in China.

It is increasingly difficult to characterize China's evolving legal system as belonging to either the civil law or common law family, ${ }^{33}$ simply because the contemporary Chinese legal system has been tremendously influenced by Anglo-American law. It is submitted that, although China has extensively borrowed legal concepts, principles, terminologies, institutions, and procedures from Anglo-American jurisdictions (most significantly the United States), it remains a civilian jurisdiction, at least insofar as sources of law are concerned. As in countries in the Romantic and Germanic families, "enacted law or legislation ... is apparently the primary, almost exclusive, source of law today' 34 in China. Case law has never gained legitimacy in China, although more and more court decisions are being published and studied by law students as persuasive legal materials. It is important to remember, moreover, that the so-called 'Chinese characteristics' should always be borne in mind: courts in China often act like legislative bodies, making China distinguishable from other civil law countries at least with respect to law-making. ${ }^{35}$

\subsubsection{Legislative Bodies}

State organs at different levels are authorized by the PRC Constitution and the Legislation Law ${ }^{36}$ to enact laws, regulations, or other normative

\footnotetext{
31 Keller (1994), p. 711.

32 Chen A.H.Y. (2004), p. 111.

33 See generally Chen A.H.Y. (2000).

34 David and Brierley (1985), p. 102.

35 See generally Peerenboom (2006).

36 Zhonghua Renmin Gongheguo Lifafa, adopted on 29 April 2000 by the National People's Congress.
} 
documents. As this section will show, different legislative bodies have different powers, while the enactments they have made, generally called 'laws', actually have different designations and degrees of binding force. Under the Chinese constitutional rules, the following organs have power to make laws or normal documents:

- The National People's Congress or NPC (Quanguo Renmin Daibiao Dahui), and its Standing Committee (Changwu Weiyuanhui)

- The State Council (Guowuyuan), which is China's central government

- People's congresses at the provincial level

- Ministries and commissions under the State Council

- Provincial governments

- Self-regulatory organizations

\subsubsection{Falï (Laws) Made by the NPC and its Standing Committee}

Under the Chinese constitutional principles, the NPC is the country's highest state organ and the source of power for all other state organs. According to Article 7 of the PRC Legislation Law, the NPC and its Standing Committee, being the national legislature, 'exercise the legislative power of the State'. As a matter of legislative principle, only the legislation enacted by the NPC or its Standing Committee can be designated as 'laws' (falï). Further, only the NPC has the power to make and amend 'basic laws' (jiben falï), a term that is not clearly defined in China's Constitution. ${ }^{37}$ In the economic arena, the Legislation Law stipulates that 'laws' must be enacted to govern the country's basic civil and economic systems. ${ }^{38}$ The Company Law, Securities Law, General Principle of Civil Law (GPCL), Partnership Law, Property Law, Enterprise Bankruptcy Law, etc., are all such basic laws that either directly or indirectly govern.

\subsubsection{Xingzheng Fagui (Administrative Regulations) Made by the State Council}

The State Council, which is the top authority in the executive branch, is also a legislative body in China, with law-making authority immediately

\footnotetext{
37 Legislation Law, Article 7.

38 Legislation Law, Article 8.
} 
below the NPC and its Standing Committee. Only the legislative enactments of the State Council may be designated as 'administrative regulations' (xingzheng fagui), or simply 'regulations'. Under the Legislation Law, the central government may formulate administrative regulations in the following situations: (a) when it is necessary to enact regulations to implement provisions of law; (b) when it is necessary to enact regulations to govern matters within the administrative functions and powers of the State Council as stipulated in the PRC Constitution; and (c) when the State Council is delegated the law-making power by the NPC or its Standing Committee to enact regulations for matters originally within the national legislature's exclusive legislative jurisdiction. ${ }^{39}$ In fact, from 1983 to 1985, the NPC and its Standing Committee delegated their law-making power three times to the State Council, for matters mainly relating to economic affairs. ${ }^{40}$ In reality, the State Council and its departments form, de facto, the most powerful law-making body in China.

Enactments of the State Council may be entitled 'regulations' (tiaoli), 'provisions' (guiding), or 'measures' (banfa), depending on the scope of subject matter. When the State Council exercises delegated law-making power, its enactment will be called a 'provisional' (zanxing), ${ }^{41}$ implying that formal statutes will eventually be enacted by the NPC or its Standing Committee in due course. ${ }^{42}$ In the area of corporate and securities law, the most important set of administrative regulations is the Company Registration Regulations.

\subsubsection{Bumen Guizhang Made by the Ministries under the State Council}

The various ministries, commissions, and bureaus and the People's Bank of China (which is China's central bank) are authorized to promulgate departmental rules (bumen guizhang) within the limits of their respective power. The rules, promulgated by either one ministry alone or by several ministries jointly, should be made only pursuant to and for the purpose of enforcing laws or administrative regulations. ${ }^{43}$ As a matter of fact,

\footnotetext{
39 Legislative Law, Article 56.

40 Chen A.H.Y. (2004), p. 104.

41 Zanxing may also be translated as 'interim' or 'tentative'.

42 The scope of matters governed by 'regulations' is the widest, that of 'measures' the narrowest, and that of 'provisions' finds its place in between the latter two. See Chen A.H.Y. (2004), p. 105.

43 Legislation Law, Article 71.
} 
departmental rules, forming the largest group of normative legal documents, constitute the most relevant and practical body of law for the daily life of ordinary citizens and businesses.

Of the State Council's 28 ministries and commissions, several of them could legislate in the area of corporate and securities law. The State Administration of Industry and Commerce (SAIC), in charge of the registration of enterprises, certainly make rules in this area. Shareholders in China are probably most familiar with the China Securities Regulatory Commission (CSRC), which, as the state regulator of China's securities markets, issues the most corporate and securities rules, covering, inter alia, corporate articles of association, corporate governance, corporate finance, information disclosure, mergers and acquisitions, shares transfer, and the listing and delisting of companies. The Ministry of Commerce, empowered with the authority to regulate all types of foreign investment in China, make rules in relation to foreign participation in Chinaincorporated companies. The Ministry of Finance promulgates rules relating to companies' accounting practices, as well as related-party transactions. The State-owned Assets Supervision and Administration Commission (SASAC) enacts rules concerning the administration of state assets in enterprises. The National Development and Reform Commission (NDRC), believed to be the most powerful ministry under the State Council, is in charge of formulating the country's macroeconomic development policies and strategies, and it occasionally makes rules that concern the regulation and operation of companies. Other ministries could also be involved in making rules governing business enterprises.

A set of departmental rules may have the generic designation of 'provisions' (guiding) or 'measures' (banfa). Apart from guizhang, the State Council and its ministries promulgate from time to time other forms of official documents, including 'orders' (mingling), 'decisions' (jueding), 'notices' (tongzhi), 'communications' (tongbao), 'replies' (pifu), 'opinions' (yijian), and 'guidelines' (zhiyin, or zhidao yijian), many of which are used as normal documents to regulate business organizations. ${ }^{44}$

\subsubsection{Difang Falu Fagui (Local Enactments)}

Governments at the provincial level, including provinces, autonomous regional municipalities directly under the central government, and large

44 Chen A.H.Y. (2004), pp. 106-7 (noting these documents 'are authoritative to various degrees, and insofar as some of them provide for rules of general application, they may also be regarded as a source of legal norms'. 
cities, are granted law-making power. According to the Legislation Law, two kinds of 'local laws' may be enacted. The first category is 'local regulations' (defang fagui) made by local people's congresses and their standing committees (the 'local legislature'). They may enact local regulations 'in light of the specific conditions and actual needs of their respective administrative areas, provided that such regulations do not contradict the Constitution, as well as, the laws and the administrative regulations made under the Constitution' ${ }^{45}$ In the spirit of local law regulating local affairs, the Legislation Law empowers the local legislature to enact local regulations on any matters not yet governed by any national laws or administrative regulations. As Professor Albert Chen has noted, this created 'room for innovation in local regulations which can pave the way for the enactment of national laws on particular subjects' ${ }^{46}$

Another kind of 'local law' is local rules (defang guizhang), made by governments at the level of provinces, autonomous regions, municipalities, and large cities, for matters concerning the implementation of national laws, administrative regulations, or local regulations. ${ }^{47}$

As previously noted, in the area of corporate law, local regulations, especially those made by governments in Shenzhen and Shanghai, preceded national legislation. For example, long before the 1993 Company Law, and even the two standard opinions, the Shenzhen municipality had enacted rules to regulate the restructuring of its SOEs. ${ }^{48}$ In these days, although national laws, regulations, and rules are becoming increasingly pervasive and cover almost all areas of corporate and securities matters, the existence of many local corporate rules demonstrates that local law could still play a significant role in creating innovative legal institutions as well as filling the gaps left by national law.

\subsubsection{Sifa jieshi (Judicial Interpretations): Case Law's Equivalent?}

China's legal system is officially a civil law system, in which the decisions of courts constitute guidance, but not law, with respect to the subject matter. As Peerenboom (2006) observes, unlike their counterpart in common law jurisdictions, Chinese courts theoretically do not possess the power to 'make law'. 'Their role is to apply law to the facts. If the laws or regulations are unclear, the courts are supposed to seek

\footnotetext{
45 Legislation Law, Article 63.

46 Chen A.H.Y. (2004), p. 109.

47 Legislation Law, Article 73.

48 See supra note 21 and the accompanying texts.
} 
guidance and clarification from the entities that promulgated the laws or regulations.' 49 Given that statutes cannot possibly be applied without proper interpretation, especially in the context of adjudication, a legal system must provide either rules of statutory interpretation or authoritative precedent or both, to guide interpretation. ${ }^{50}$ In China, in addition to the law interpretation system, which places the power of interpreting laws in the hands of the NPC Standing Committee, 'a rudimentary system has evolved which might be interpreted as the functional equivalent of case law in other jurisdictions'. ${ }^{51}$ This essentially refers to the power of the Supreme Court to make the so-called 'judicial interpretations' (sifa jieshi). As Peerenboom (2006) remarks,

What is distinctive about China's legal system is that the Supreme People's Court (SPC) makes law in a much more direct and visible way. Every year the SPC issues a variety of interpretations, regulations, notices, replies, opinions and policy statements (collectively, 'interpretations'). Most are binding upon the courts; others are highly persuasive and likely to be followed by the courts. Sometimes they are rather general; other times they are very specific and issued in response to an inquiry from [a] lower court in regard to a particular case pending before the court. ${ }^{52}$

A 1981 NPC Standing Committee decision began to permit the SPC to promulgate judicial interpretations in the reform era. ${ }^{53}$ The SPC has issued a series of provisions to elaborate on its law interpretation work, the most recent being the 2007 SPC Provisions on Judicial Interpretation Work. ${ }^{54}$ In essence, judicial interpretations, having the binding force of law, could only be promulgated by the SPC. They may take the forms of 'interpretations' (jieshi), 'provisions' (guiding), 'replies' (pifu), and 'decisions' (jueding). Interpretations deal with the application of a specific law or a type of case or problem; provisions are used to create norms or opinions relating to adjudication; replies are answers to inquiries from

49 Peerenboom (2006), p. 2.

50 In addition, 'the courts are often required to expound the meaning of a statutory provision by ... deciding whether or not it applies to a particular set of facts'. See Mayson, French and Ryan (2006), p. 23.

51 Chen A.H.Y. (2004), p. 118.

52 Peerenboom (2006), p. 2.

53 Resolution of the NPC Standing Committee on Strengthening the Work of Interpretation of Law. See Chen A.H.Y. (2004), p. 119.

54 Zuigao Renmin Fayuan Guanyu Sifa Jieshi Gongzuo De Guiding, Fafa (2007) Di 12 Hao, promulgated on 23 March 2007. 
the provincial courts regarding issues concerning concrete application of law; and decisions are used to revise or abolish judicial interpretations. ${ }^{55}$

The three judicial interpretations on the application of the Company Law (Company Law Interpretation (I), Company Law Interpretation (II), and Company Law Interpretation (III)) are the three most important sifa jieshi ever issued for corporate and securities disputes by the SPC. In addition, the SPC has promulgated several interpretations on disputes involving foreign-invested enterprises, SOE restructuring, and securities misrepresentation in recent years.

Given the increasing convergence of the Chinese legal system with the Anglo-American legal tradition, many would wonder whether decided cases also play a role in the courts' adjudication of corporate and securities disputes. But even accepting that China is still a civilian jurisdiction, the rather simplistic view that civil law excludes judicial precedent as a source of legal authority is no longer accepted. As David and Brierley (1985) note, in countries such as France or Germany, 'cases have been of primary importance in the evolution of some branches of the law'. ${ }^{56}$ Certainly, judicial decisions do not constitute law in China. ${ }^{57}$ However, it is correct to observe that court decisions 'do generate legal norms and have persuasive or even binding force in practice'. ${ }^{58}$ The most noticed cases are those judgments or summary of judgments selected and published by the SPC in the Gazette of the Supreme People's Court, which are considered 'authoritative and an important means through which the Supreme People's Court provides guidance to lower courts with regard to their adjudicative work' ${ }^{59}$ Many published cases, some of which will be discussed in the following chapters, are about corporate and securities disputes.

\subsubsection{Rules Made by Self-regulatory Organizations}

The Securities Association of China (SAC) and the two securities exchanges, namely the Shanghai Stock Exchange (SSE) and the Shenzhen Stock Exchange (SZSE), are officially considered 'self-regulatory organizations' (SROs) in China's securities markets. They are hence empowered to make self-regulatory rules. The binding nature of these

\footnotetext{
55 Id, Article 6.

56 p. 133.

57 Chen A.H.Y. (2004), p. 128.

58 Chen A.H.Y. (2004), p. 128.

59 Chen A.H.Y. (2004), pp. 128-9.
} 
rules is augmented because the so-called SROs are under tight governmental control, which lends the rules they issue the weight of state endorsement. At this stage in the development of the PRC legal system, the SROs, which enjoy almost no independence from the government, are themselves de facto state organs.

Under the PRC Securities Law, the SAC, established in 1991, is an SRO with legal personality. ${ }^{60}$ According to the SAC's own articles of association, it is also a non-profit organization under the supervision of the CSRC and the Ministry of Civil Affairs. ${ }^{61}$ All securities companies (Chinese brokers, dealers, and investment banks) must join the SAC.62 The law also authorizes the SAC to formulate membership rules, mediate disputes between members and between members and their clients, oversee the conduct of members, and initiate disciplinary action 'in the event of members' violation of laws, administrative regulations or the articles of association of the SAC'. ${ }^{63}$ In addition, the CSRC has authorized the SAC to facilitate innovation in the securities industry, manage the professional qualification system, supervise the disclosure of members' information, promote standardization, communication, and training with respect to securities information technology, facilitate compliance with applicable regulations, and supervise and manage the Share Transfer System. ${ }^{64}$

Much related to the operation of companies is, in fact, the Share Transfer Agent System (STAS). ${ }^{65}$ The STAS is managed by the SAC and serves a function similar to an over-the-counter market both for companies that have been recently delisted from one of the two stock exchanges and those originally listed on STAQ and NET, two electronic trading systems dismantled by the government in 1998 for unknown reasons. Since June 2001, the SAC has issued a host of rules concerning share trading on STAS.

\footnotetext{
60 Securities Law, Article 174.

61 The Articles of Association of the Securities Association of China, Articles 1 and 3 (available at http://www.sac.net.cn).

62 Securities Law, Article 175.

63 Securities Law, Article 176, paras. (4), (5), and (7).

64 CSRC (2006), p. 33.

65 Daiban Gufen Zhuanrang Xitong.
} 
The Securities Law and the 2001 CSRC Measures for the Administration of Securities Exchange ${ }^{66}$ define a securities exchange as a 'selfregulatory legal person which provides the venue and facilities for centralized trading of securities and which is responsible for organizing and supervising of securities trading'. ${ }^{67} \mathrm{~A}$ stock exchange is, however, not necessarily a non-profit organization under the new Securities Law.

Securities exchanges are authorized to enact rules for the following purposes:

1. Formulating exchange listing rules, share trading rules, exchange membership rules, and other rules in accordance with securities laws and administrative regulations, subject to the approval of the CSRC;

2. Safeguarding the security and fairness of centralized exchange trading;

3. Monitoring securities trading at all times and supervising information disclosure of listed companies and relevant persons; and

4. Taking disciplinary actions against violators of securities laws and regulations.

The two securities exchanges have promulgated hundreds of rules to govern listing, trading, information disclosure, corporate finance, corporate governance, mergers and acquisitions, and even corporate social responsibility. From a commercial perspective, for listed companies, securities firms, and investors, complying with these trading and listing rules can be just as important as meeting the requirements of law. Needless to say, exchange rules are 'soft law' in nature, and are treated as contractual arrangements by the courts.

\subsubsection{Custom}

As observed in David and Brierley (1985), '[a]ccording to a sociological concept of the sources of law, custom plays a preponderant role in all legal systems; and in developing or applying the law, legislators, judges and authors are, as a matter of fact, more or less consciously guided by the opinion and custom of the community'. ${ }^{68}$ Custom as a source of law

66 Zhengquan Jiaoyisuo Guanli Banfa, promulgated by the State Council Securities Commission in 1997; revised and re-promulgated by the CSRC on 12 December 2001.

67 Securities Law, Article 102.

68 David and Brierley (1985), p. 130. 
is recognized in China's legal system, especially with respect to civil and commercial disputes. ${ }^{69}$

\subsubsection{Legal Writings}

Just as in many other countries, works of legal scholarship play an eminent role in the legal system, although they are not formally recognized as a source of law. This is largely because legal writings shape legal 'doctrine', which is of fundamental importance to the formation and application of written laws in civil law countries and the creation of common law in common law countries. The importance of legal writing in the civil law tradition is beautifully summarized in David and Brierley (1985) in the following passage, which to some degree also sheds light on China's situation:

One may, of course, define law as only enacted rules. Nevertheless, for the person who takes a realistic approach and has a more comprehensive - and to our mind, more exact - view, doctrine is now, as in the past, a very important, living source of law. This is shown by the fact that it creates the legal vocabulary and ideas which legislators subsequently use; it is even more evident from the fact that doctrinal writing establishes the methods by which law will be understood and statutes interpreted. There is, further, the influence that legal scholarship can exercise on the legislators themselves; often the latter merely give expression and effect to tendencies that have developed doctrinally, or enact laws which have been conceived by legal writers ... [Legal writing] also plays a role in the application of enacted law. ${ }^{70}$

Scholarly writing is not a formal source of law in China. It may never be admitted that there is not one 'enacted writing' and that there will always be different scholarly views about the same things. Yet the role of legal scholars in China should not be underestimated. They were heavily involved in the legislative process of major laws, including inter alia, the Company Law, and the Securities Law. To some extent, it is not incorrect to say that the scholars were themselves the lawmakers, as the drafts of law made by them were largely accepted by the NPC and other legislative bodies. Furthermore, some courts, especially the SPC and some provincial high courts, have developed the tendency to consult

\footnotetext{
69 Liang (2004), p. 28.

70 David and Brierley (1985), p. 135.
} 
prominent scholars in their adjudication of legal disputes. One commentator hence suggests that this indicates that legal writing may be regarded as an 'indirect source of law' (jianjie fayuan) in China. ${ }^{71}$

\subsubsection{Understanding the Complex Hierarchical Structure of the Chinese Legal Order}

It is essentially important to understand the hierarchy of law in China. As discussed above, the multiple legislative bodies have made numerous laws and regulations, often on the same subject. Conflicts and inconsistencies have also inevitably arisen between laws made by different legislative bodies. For instance, with respect to the registration of a company, there are provisions in the national Company Law, a special administration regulation enacted by the State Council, as well as departmental rules released by the State Administration of Industry and Commerce. Two interrelated questions therefore arise: (1) which level of laws has higher legal effects? and (2) which law should a court apply if there are conflicts between different laws?

Under the Constitution and the Legislation Law, law enforcement organs should observe the following principles on the hierarchy of legal order:

- The PRC Constitution has the highest legal authority, and no other laws, administrative or local regulations or rules may contradict it. ${ }^{72}$

- The legal effect of laws (made by the NPC and/or its Standing Committee) is higher than that of administrative regulations, local regulations, and rules. ${ }^{73}$

- The legal effect of administrative regulations is higher than that of local regulations and rules. ${ }^{74}$

- The legal effect of local regulations is higher than that of local rules made by governments of the same and lower levels. ${ }^{75}$

- The legal effect of the departmental rules made by different central departments is equal between those departments, and the effect of departmental rules and local rules is equal between the departments

\footnotetext{
71 Liang (2004), p. 27.

Legislation Law, Article 78.

Legislation Law, Article 79.

Legislation Law, Article 79.

75 Legislation Law, Article 80.
} 
and local governments; their application should be confined to their respective limits of authority. ${ }^{76}$

Having identified that departmental rules and local regulations have the same legal status, the Legislation Law, however, does not solve a key problem: the conflict of authority between the central and provincial departments. As remarked in Cohen and Lange (1997), '[t]he conflict between central and local authorities will continue to handicap the development of the Chinese legal system, and to heighten the risks for foreign investors, at least until China evolves and enforces a reasonably clear and rational allocation of authority between the central and provincial governments'. ${ }^{77}$ Further, '[o]ften investors are caught in the middle, between the more investor-friendly local authorities and the more macrooriented central authorities, each offering their own - often sharply divergent - visions of the applicable regulatory framework and the proper way to proceed. In addition, the vastness of China and the existence of entrenched local power bases often makes it difficult for the central government to enforce laws it adopts for the benefits of investors'. ${ }^{78}$

Although the legal status of administrative regulations is higher than local law according to the Legislation Law, many rules - probably those most relevant to the corporate world - are promulgated by central ministries such as the SAIC, the CSRC, and the SASAC. Many localities have also adopted regulations and rules to regulate corporate activities in their own districts. Article 86 attempts to provide a solution for conflict of laws in this situation, and stipulates that, where there is inconsistency between local regulations and departmental rules on the same matter, and the governing rules cannot otherwise be decided, the State Council can make a decision that local regulations should prevail. But if the State Council determines that departmental rules shall apply instead, the case should be submitted to the NPC Standing Committee for a ruling. ${ }^{79}$ As an NPC procedure is time-consuming, this provision probably does not offer much practical solace to the courts, which are faced with disputes on a daily basis.

The Legislation Law does not address the place of judicial interpretations in the hierarchy of legal order. In theory, an 'interpretation' should not contradict the original enactment it aims to interpret. In practice, judicial interpretations have gone far beyond that, making the SPC a de

\footnotetext{
76 Legislation Law, Article 82.

77 p. 349.

78 Id.

79 Legislation Law, Article 86, para. 2.
} 
facto legislative body, a status not recognized by the Legislation Law. Given the tight control of the SPC over the lower courts, its judicial interpretations are more faithfully enforced by courts than many laws, as the interpretations provide timely, practical, and specific responses to concrete issues.

On the courts' choice of law, an SPC document released in 2004 is very illustrative. Entitled 'SPC Meeting Minutes on the Application of Law Issues in the Trial of Administrative Cases', ${ }^{80}$ it is not itself a judicial interpretation, but would definitely guide the adjudication practice of courts at all levels. The Minutes stipulate the following principles with regard to courts' choice of law:

- In trying administrative cases, the people's court shall apply laws, administrative regulations and local regulations, and make reference to rules.

- Interpretations of laws, decisions, orders or other official normative documents issued by the State Council departments and local governments are not binding upon courts; they will be applied in trial only after the court has reviewed the legality of those documents under laws or administrative regulations.

- The court will apply a higher-level law if there is inconsistency between laws.

- If there is inconsistency between departmental rules and local regulations, the court will make choices according to the following principles: (1) departmental rules authorized to implement the laws or administrative regulations should take priority; (2) departmental rules concerning matters which require national actions or concerning foreign trade or foreign investment shall take priority; (3) local regulations concerning purely local matters shall take priority.

Although the Minutes concern, as a matter of law, only court adjudication of administrative cases, they provide significant guidance for the trial of civil and commercial disputes. Furthermore, one has to bear in mind that most official normative documents are administrative in nature. It is also worth noting that the Minutes establish a formal mechanism of judicial review of legality of laws. According to the Minutes, although Chinese courts do not have the power to invalidate any written laws,

80 Zuigao Renmin Fayuan Guanyu Shenli Xingzheng Anjian Shiyong Falv Guifan Wenti de Zuotanhui Jiyao, Fafa (2004) No. 96, promulgated by the SPC on 18 May 2004. 
regulations, or rules, they seem to have great discretion to choose the law they wish to apply.

\subsection{THE CONCEPT, PURPOSES, AND PRINCIPLES OF COMPANIES AND COMPANY LAW IN CHINA}

\subsubsection{Development of Corporate Law Driven by Legal Transplantation and Local Needs}

As noted above, the corporate law regime, as it currently stands and possibly evolves, could pose a theoretical challenge to the conventional wisdom on the law of business corporations. First, does the evolution of corporate law in China show convergence or divergence in the structure and practice of corporate law globally? One stream of the corporate law literature, represented in Hansmann and Kraakman (2001), has famously declared 'the end of history for corporate law'. The development of Chinese corporate law, in the sense that it has extensively borrowed institutions from both Anglo-American and European Continental jurisdictions, has provided evidence of the power of one of the world's largest markets, once an entirely socialist, plan-based economy, to induce convergence. If a definition needs to be given to the company, it is firstly understood as a creature of law, or a legal artifice, offering limited liability to its owners. ${ }^{81}$ In the wake of China's marching toward the 'socialist market economy', the companies incorporated in China are, at least in theory, expected to have the typical attributes of modern corporations. Those include, most well known, '(1) full legal personality, including well-defined authority to bind the firm to contracts and to bond those contracts with assets that are the property of the firm, as distinct from the firm's owners; (2) limited liability for owners and managers; (3) shared ownership by investors of capital; (4) delegated management

81 From a theoretical perspective, the origin of the company can be explained by two conflicting theories, namely the concession theory and the contract theory. The concession theory claims that the corporation is a creation of the state and that its legal power is derived from the state. In contrast, the contract theory maintains that the corporation is an association formed by the shareholders through agreement, namely it is a nexus of contracts rather than a creation of the state. As we shall see from provisions of the PRC Company Law, there is no doubt that the company is viewed as a legal creature rather than a contractual product. 
under a board structure; and (5) transferable shares'. ${ }^{82}$ As Hansmann and Kraakman (2004) point out, these attributes are to some extent universal in nature: 83

These characteristics are ... included by the economic exigencies of the large modern business enterprises. Thus, corporate law everywhere must, of necessity, provide for them. To be sure, there other forms of business enterprise that lack one or more of these characteristics. But the remarkable fact - and the fact we wish to stress - is that, in market economies, almost all large-scale business firms adopt a legal form that possess[es] all five of the basic characteristics of the business corporation. Indeed, most small joint-owned firms adopt this corporate form as well, although sometimes with deviations from one or more of the five basic characteristics to fit the special needs of closely held firms ... Self-evidently, a principal function of corporate law is to provide business enterprises with a legal form that possesses these five core attributes.

Hansmann and Kraakman (2004) further remark that '[b]usiness corporations have a fundamentally similar set of legal characteristics - and face a fundamentally similar set of legal problems - in all jurisdictions' ${ }^{84}$

Indeed, the laws of corporations around the world, when they were first enacted, were very similar ${ }^{85}$ largely because of the inherent nature of Western commerce and capitalism. The transplantation of corporate law from leading origin countries of the civil law and common law families, mainly England, France, Germany, and the United States, to countries in other regions has led to tremendous similarities in the basic legal framework of corporations across the globe. However, as the corporate world grew, divergence began to emerge among the origin countries, as they had to provide legal and institutional solutions to indigenous problems that occurred in different national settings that bore - sometimes slightly and other times extremely - different legal culture and philosophy from others. As a result, in terms of corporate law, the origin countries differ "in how they responded to the challenges of the rapid growth of the enterprise and financial sectors and to the booms and busts

82 Hansmann and Kraakman (2001), p. 440. Clark (1986, p. 2) identifies four characteristics of the corporation: '(1) limited liability for investors; (2) free transferability of investor interests; (3) legal personality (entity-attributable powers, life span, and purpose); and (4) centralized management'. See also Monks and Minow (2004), p. 11.

83 pp. 1-2.

84 p. 1.

85 Pistor et al. (2003), p. 89 (noting '[w]hen the first corporate statutes were enacted, there were remarkably few differences among countries and legal families'). 
of financial markets that accompanies it' ${ }^{86}$ In spite of the differences, the corporate laws in the origin countries have been, in various degrees, successful. Time is to be credited for this: the development of capitalism and credit culture in Western Europe and North America has lasted for over two centuries, a time span wide enough for those countries to adjust and rationalize their regulatory and market institutions of corporations through learning from experiment and falsification, or trial and error.

In the successful origin countries, a central task of corporate governance is to control the 'controller', which is normally the management of the corporations. But countries differ in the tools used for corporate governance; and '[m]ost important are differences, particularly between the common law and civil law families, in the allocation of control rights' ${ }^{87}$ With few exceptions, the board of directors is the primary governance organ in the Western corporations. Over the years, two types of board structures have evolved, namely the unitary board and the two-tier board. The unitary system, adopted in Anglo-American countries, allows for only one board, or the board of directors, which 'directs' and oversees the company, including proving strategic guidance for company, and appointing and monitoring the performance of the executives. In the Anglo-American systems, independence of the board of directors is supposed to be ensured by its composition, namely the board is composed of mainly independent directors. In the two-tier board structure, most notably adopted by Germany, the governing body of the corporation comprises two separate boards, including the management board (also called board of directors), and the supervisory board. The supervisory board chooses the directors of the management board and monitors their performance.

In the area of corporate law, developing and transition countries have their legal system transplanted from the one or two of the origin countries mentioned above. Pistor et al. (2003) survey the transplant effect of six representative countries that adopted foreign law $^{88}$ and concludes that

[c]ountries that adopt foreign law are frequently unprepared for it or the changes it brings. It is therefore not surprising that the new law does not

\footnotetext{
86 Pistor et al. (2003), p. 94.

87 Pistor et al. (2003), p. 94.

88 The countries in this survey have transplanted their corporate law from the following origins: Chile, Colombia, and Spain (from French law); Israel and Malaysia (from English common law); and Japan (from German law and U.S.
} law). 
become well incorporated into the institutional landscape or contributes to an ongoing process or institutional change. ${ }^{89}$

The conclusion's overgeneralization is apparent..$^{90}$ After all, companies in quite a number of countries that have transplanted legal systems from abroad are running well: although the corporate law of New York State preceded Britain's 1848 Joint Stock Company Act by over 30 years, the U.S. legal system indisputably finds its origin in England. Further, a country's adoption of foreign corporate institutions might respond to an internal need to rationalize its enterprise sectors. Despite this weakness, the survey correctly suggests that 'legal transplantation is not an easy (and certainly not a short-term) solution for countries with less developed legal systems'. ${ }^{91}$

China adopted its corporate law through a 'transplant'. As its Company Law (or 'Corporation Law' as it is translated by some) shows, China has imported the organizational structures of Western capitalist business into its own enterprise sectors. ${ }^{92}$ However, as some commentators observe:

Difference from Western models bracket this general similarity at both the broad level, in ideology and over objective, and the technical level, in details and specific rules. [sic] The melding of Western forms with the goal of promoting a 'socialist market economy' has produced a Corporation Law with distinctly Chinese characteristics..$^{93}$

Further, although China's corporate law embraces a significant amount of institutions imported from foreign sources, it is difficult to identify the single most significant 'origin' country. Broadly speaking, the Chinese system is a hybrid one, containing institutions borrowed from both the common law family, mainly the United States, and continental civil law family, i.e. Germany. This is most visible in the board structure of China's listed companies, which have both a supervisory board and independent directors in the management board. Even with these two 'safety nets', corporate governance in China's listed companies still remains very unsatisfactory. ${ }^{94}$ In fact, both empirical studies and analysis

\footnotetext{
89 Pistor et al. (2003), p. 98.

90 The authors of this survey admit this by saying 'the small size of the sample cautions us against overgeneralization'. See Pistor et al. (2003), p. 109.

91 Pistor et al. (2003), p. 109.

92 Art and Gu (1995), p. 275.

93 Art and Gu (1995), p. 275.

94 Wang (2004a), pp. 40-42 (discussing the poor corporate governance of China's listed companies).
} 
of the legal framework show that the supervisory board and the independent directors, the 'strange partners' in China's listed companies, have not significantly improved the overall corporate governance of those companies.

Indeed, although business corporations in China possess the same fundamental legal characteristics as seen in all jurisdictions, and are plagued with some similar legal problems, the corporate law system in China demonstrates strong Chinese characteristics. Among the problems that have been alleged to cause most, if not all, the scandals in corporatized enterprises, the most salient are conflict of interests between the shareholders (owners) and managers and between the majority shareholders and minority shareholders, the two classic agency problems of company law. In SOEs the state is normally the majority shareholder. There are also many other companies, including some listed companies, which are controlled by private owners. In essence, the agency problems in Chinese companies are not fundamentally different from those in other market economies.

Therefore, subject to some universal and indigenous exceptions, ${ }^{95}$ there must be many Chinese companies that have the core characteristics of modern corporations. These characteristics are required by the nature of a market economy, as they, individually or in combination, 'offer important efficiencies in organizing the large firms with multiple owners that have come to dominate developed market economies'.96 Anyone who has noticed the sheer number of shareholders and the growing shareholder activism in many listed companies in China would understand the need for Chinese companies to perform the same functions as their foreign counterparts. However, in a country that is still in the process of transitioning from plan to market, its enterprises often are either striving to learn how to behave like corporate citizens, or just happy to act as units that, under the disguise of independent corporate structure, are actually not independent of other entities or individuals.

In this view, principles of Chinese company law should be understood in their unique economic, political, and culture contexts. Article 1 of the PRC Company Law is a telling presentation of this need, as it states: 'This Law is formulated in order to standardize the organization and activities of companies, protect the lawful rights and interests of companies, shareholders and creditors, safeguard the social and economic

95 Such as restrictions on the transfer of shares in limited liability companies, or the doctrine of piercing the corporate veil, which will be discussed in later chapters.

96 Hansmann and Kraakman (2004), p. 440. 
order and promote the development of the socialist market economy'. Indeed, the multiple objectives of the law demonstrate strong Chinese characteristics. For example, an important social fact in China is that the state sector, albeit diminishing, still dominates the country's economy, at least in terms of its leading role in shaping and implementing central and local industry policies. This is, however, accompanied by another phenomenon: China is also experiencing the largest privatization of assets in world history. As a result, the state business sector has withdrawn significantly from many forefronts of the economy, while the private sector has been growing so rapidly that it has already become the country's 'major driver of growth in productivity and new jobs'.$^{97}$ Nevertheless, the vast majority of companies listed on China's two stock exchanges are still state controlled. ${ }^{98}$

In this light, the regulation and governance of companies in China demonstrate some distinctive Chinese characteristics, in addition to the universal characteristics. Those characteristics will be explored at appropriate points in later chapters.

\subsubsection{The Concept of Companies in China}

Discussing the concept of company under Chinese law cannot really attempt precisely to define the concept 'company', as 'the word company has no strictly legal meaning'. ${ }^{99}$ Scholarly writings define the company as a kind of social organization legal person (Shetuan faren), which means an association of persons organized for certain purposes, as opposed to a property-based legal person (Caituan faren), which normally refers to a foundation or trust constituted as a legal person. ${ }^{100}$ Article 2 of CL 2005 simply states that "For the purposes of this Law, the term "companies" shall mean limited liability companies and companies limited by shares established pursuant to this Law in China'. Obviously, this provision does not provide a workable definition of companies.

\footnotetext{
97 OECD (2005), p. 80.

98 Id.

99 Davies (2003), p. 3 (citing Buckley J in Re Stanley [1906] 1 Ch. 131 at 134). Soderquist et al. (1999, $§ 1: 2.3)$ define a U.S. corporation as 'an entity that consists of an intangible structure for the conduct of the entity's affairs and operations, the essence of which is created by the state, and that possesses the rights and obligations given or allowed it by the state, which rights and obligations more or less parallel those of natural persons'.

100 Shi Tiantao (2006), p. 6; Zhao Xudong (2006), pp. 6-7.
} 
Nonetheless, under the PRC Company Law, or at least according to the law on the books, a Chinese company features the core structural characteristics of the modern business corporation, including legal personality, limited liability, centralized management, shareholder's ownership and residual claims, and free transferability of shares.

\section{Legal personality and limited liability}

Article 3 of CL 2005 provides:

A company is an enterprise legal person which has independent legal person property and enjoys legal person property rights. A company shall be liable for its debts to the extent of all its property.

A shareholder of a limited liability company shall be liable to the company to the extent of the capital contribution it subscribes. A shareholder of a company limited by shares shall be liable to the company to the extent of the shares it subscribes.

Article 3 encompasses two of the core characteristics of modern business corporations, namely legal personality and limited liability. The operation of these two principles under China's corporate law regime will be discussed in detail in Chapter 5 of this book. A few general points should nevertheless be outlined at this point.

A company is, firstly, an enterprise legal person. As Clark (1986) observes, 'one of the law's most economically significant contributions to business life, and one often ignored by lawyers because it generates less litigation than many other contributions, has been the creation of fictional but legally recognized entities or "persons" that are treated as having some of the attributes of natural persons' ${ }^{101}$ A legal person is one of the key institutions in the civil law system of China, defined in the PRC General Principles of Civil Law (GPCL) as 'an organization which possesses both the capacity for civil rights and the capacity for civil acts and which enjoys civil rights and assumes civil obligations independently according to law'. ${ }^{102}$ The legal criteria determining the valid establishment of a legal person include (a) establishment strictly in accordance with the law; (b) possession of the necessary property of capital; (c) possession of a name, organizational structure, and premises; and (d) ability to bear civil liability independently. ${ }^{103}$

The legal person doctrine suggests that PRC Company Law treats the company as a legal creature, which could not exist without the law

\footnotetext{
101 Clark (1986), p. 15.

102 GPCL, Article 36.

103 GPCL, Article 37.
} 
creating it. In other words, the firm must be established by law according to the required procedures (the so-called incorporation process). By incorporation, the firm acquires the status of a legal person and becomes the holder of legal rights and duties. This gives it the ability to 'own assets that are distinct from the property of other persons, such as the firm's investors, and that the firm is free not only to use and sell but most importantly - pledge to creditors'. ${ }^{104}$ Specifically, corporate personhood allows the company to have its own name, to make by-laws for self-governance, to enter into legal transactions, to sue and be sued, and to be held accountable for its debts. Shareholders of the company share collective ownership in the company, and own equity interest in the company individually. They are, however, never owners of the assets of the company, either collectively or individually.

With respect to corporate ownership, a strong Chinese characteristic is that the Company Law does not explicate whether the company has ownership of its own assets. The use of the term 'ownership' was intentionally avoided and replaced with 'enterprise legal person property rights', although some commentators have argued that these two are functionally equivalent terminologies. ${ }^{105}$ Significantly, as corporate assets include the capital contributions made by the shareholders, capital contributions cannot be withdrawn by the shareholders once they are made; otherwise, it would be an infringement of corporate property rights. In this spirit, CL 2005 abandons a provision of CL 1993, which provided that 'the ownership of state assets in a company belong[s] to the state'. 106

Acquiring legal personality may result in perpetual existence, although, again, the language of the law is not clear. The GPCL grants a legal person full capacity with respect to having rights and obligations during its whole life, namely from its establishment to its termination. ${ }^{107}$ Presumably, the absence of explicit provisions means that, according to the Company Law, there is no prohibition on companies stipulating in their articles of association perpetual existence. Indeed, the Guidelines for Articles of Association of Listed Companies issued by the China Securities Regulatory Commission (CSRC) (hereinafter 'CSRC Model Articles') states that a joint-stock company can elect to have a fixed term

\footnotetext{
104 Kraakman et al. (2004), p. 7.

105 Zhao Xudong (2006), pp. 4-5.

106 CL 1993, Article 4, para. 3.

107 GPCL, Article 36, para. 2.
} 
of duration or simply provide for 'perpetual existence' in its articles. ${ }^{108}$ This privilege, however, cannot be taken for granted by every type of company. For instance, most foreign-invested companies would need to stipulate in their contracts and articles of association a fixed term of operation, and apply to the authorities if an extension of the business were desired. ${ }^{109}$

Article 3 also indicates that the concept of legal personality is closely tied to the concept of limited liability. Shareholders are liable to the extent of their capital contributions. This means that, by default, a shareholder's financial liability to the creditors of the company is limited to his/her investment in the company. The creditors of the company 'are limited to making claims against the assets that are the property of the firm itself, and have to further claim against the personal assets of the firm's shareholders'. ${ }^{110}$

In the context of Chinese company law, a shareholder's liability to the company is fully satisfied when his/her capital contribution is paid up. The shareholder is liable to the company to the extent of the capital contribution or shares he or she subscribes, not the amount of capital he or she has actually made. That is to say, a shareholder who has entered into an agreement to buy equity interest in a company will always be under the obligation to make up the difference if he or she did not pay the full value of the consideration.

Limited liability has lost its function as an undefeatable protective shield under the current corporate law regime in China. Amending CL 1993, CL 2005 has added a brand new provision, now Article 20 of CL 2005, which requires investors not to abuse their position as shareholders; otherwise, the court will apply the doctrine of 'piercing the corporate veil' and hold them accountable for corporate debts.

\section{Investor ownership and centralized management}

As under the company law of every other major jurisdiction, shareholders are owners of the company, but not of the assets of the company. Ownership in the firm encompasses two elements: 'the right to control the firm, and the right to receive the firms' net earnings'. ${ }^{11}$ Article 4 of

108 Guidelines for Articles of Association of Listed Companies, issued by the CSRC, Zhengjian Gongsi Zi [2006] 38 Hao, 16 March 2006.

109 See e.g. Article 13 of the PRC Law on Sino-foreign equity joint ventures (stating that whether a fixed term of operation is needed depends on the nature of the industries concerned).

110 Kraakman et al. (2004), p. 8.

111 Kraakman et al. (2004), p. 13. 
CL 2005 embodies the two elements, and states that 'Shareholders of a company shall enjoy such rights as earnings on assets, participation in major decision-making and selection of management personnel according to law'.

In terms of the right to control, the PRC Company Law gives most of the powers to determine the company's overall direction and to manage the company's day-to-day operations to the company's managers, board of directors, and supervisory board. Shareholders as owners are required to give up the powers to make decisions on all but the most fundamental issues facing the company, and to delegate the powers to the directors and managers. In this regard, China is not different from other jurisdictions, although shareholders in China ostensibly have more power than their Western counterparts under the written laws. As Kraakman et al. (2004) observe, '[d]elegated management is an attribute of nearly all large firms with numerous fractional owners. Delegation permits the centralization of management necessary to coordinate productively. Equally important, delegation of decision-making power to specific individuals notifies third parties as to who in the firm has the authority to make binding agreements'.112 Proper functioning of delegated management depends on a sound corporate governance structure, which is further discussed below.

\section{Free transferability of investor interests}

For investors, one of the biggest advantages associated with the corporate form is that they are legally guaranteed the right to transfer equity interests in the firm to others, and thereby exit the firm. In China, as in most civil law countries, a limited liability company does not issue share certificates, so that the equity stake of a shareholder is stipulated in the company's incorporation agreement as well as in the articles of associations, in the form of a figure percentage. Transfer of the equity interest takes place in a purely dematerialized fashion, on the books of the company. Equity interest transferability is subject to legal restrictions under certain circumstances. For example, the right of a shareholder to transfer his equity interest to an outsider is subject to the 'right of first refusal' of other shareholders. ${ }^{113}$

Transferability shares in a company limited by shares is a right by default under the Company Law, meaning the investors automatically have the right unless the law imposes restrictions on transferability for

\footnotetext{
112 Kraakman et al. (2004), p. 11.

113 CL 2005, Article 72.
} 
special reasons or the transferability is constrained by the investor's contractual obligations, e.g. commitments to other shareholders or to the stock exchange on which the shares are listed. In a company limited by shares, the promoters may not transfer their shares within one year from the date of incorporation. The directors, supervisors, and senior corporate officers may not transfer more than 25 percent of their total shareholding in the joint-stock company during their term of office. Their shares will be barred from transfer for one year from the date the company goes public. More such restrictions are discussed in later chapters.

\subsubsection{Revision of the Company Law: Marching Toward Rule of Law in the Corporate World?}

The 2005 revision of the Company Law is a breakthrough in the development of China's corporate law. This is not to say that the new Company Law has established a regime that is totally different from the former one; instead, the new law represents an accelerated movement in an ongoing trend toward developing a rule-based, investor protection oriented, transparent legal system for modern business companies in China. During the past two decades, there were several separate but interrelated developments in the corporate law regime, all of which can be explained by the changes brought by the 2005 Company Law.

\section{General applicability: from a law for state-owned enterprise to a general law for all types of companies}

The first law for domestic enterprises promulgated in the reform era was the 1988 Law of the PRC on Industrial Enterprises Owned by the Whole People'14 (hereinafter the '1988 SOE Law'), which is still valid and governs purely state-owned enterprises. Although the 1993 Company Law posed as a law for all kinds of companies regardless of ownership, it was designed primarily for SOEs. 'The enterprise envisaged by the Company Law is not one formed by a group of private entrepreneurs; it is a corporatized traditional SOE.' 115

The 2005 law becomes a more general corporate statute by deleting the many provisions of the 1993 law that gave special privileges or protection to SOEs. As Wang Baoshu (2007) observes, about 14 Articles in the old law specially designed for SOEs were abrogated by the new law, although the special section on wholly state-owned companies

\footnotetext{
114 See supra, $\$ 1.4 .3$.

115 Clarke (2003), p. 30.
} 
remains. ${ }^{116}$ For example, CL 1993 only permitted CLS or state-owned LLC to issue corporate bonds. ${ }^{117}$ In so doing, the new law does away with the decades-long practice of discriminating against privately-owned companies.

\section{Deregulation: from government control of enterprise to freedom of enterprise}

The most significant change in the new law is that it represents a movement from restrictive to enabling statute, thus shifting the regulatory philosophy from tight government control to deregulation. Under the new law, the freedom of enterprise, which means the enterprise and the entrepreneurs are free to operate the business and dispose of corporate resources, has gained considerably larger room. This shift is demonstrated in the following aspects:

Relaxed incorporation requirements: In the regulation of business incorporation, the new law has largely completed the process of moving from an approval system to a registration system. Under the new system, as long as the application for incorporation meets the conditions specified in the law, the companies registrar (which is normally the central and local bureaus for industry and commerce) is required to register the company. ${ }^{118}$ The number of promoters has been reduced to two from five for establishing a CLS. In addition, the new law permits an LLC to be incorporated by a single natural or legal person.

Relaxed registered capital requirements: CL 1993 required a minimum registered capital between RMB100,000 and RMB500,000 for setting up domestic LLCs, making incorporation unaffordable for many. The new law replaces this capital spread with a standard minimum capital of RMB30,000 and makes the corporate form available to more investors. ${ }^{119}$ In addition, for the first time, Chinese law allows registered capital to be partially paid, with the remainder in installments, as long as the initial contribution is not

\footnotetext{
116 Wang Baoshu (2007), p. 13.

117 CL 1993, Article 159.

118 In contrast, the application for establishing a CLS must be approved by a central ministry or provincial government on a case-by-case basis.

119 The minimum registered capital for CLS is reduced from RMB10 million to RMB5 million.
} 
less than 20 percent of the total registered capital. Most significantly, the new law expands the means of capital contribution, bringing in more varieties of non-cash assets that can be used as investment, as long as the non-cash assets are transferable and can be monetarily valued.

More discretionary and enabling rules, and expanded corporate power: CL 1993 is often described as a restrictive statute that tended to impose heavier regulation on companies. ${ }^{120}$ It was full of restrictive phrases 'should', 'must', and 'must not', which compelled companies to do or not do specified things. Under CL 1993, the articles of association, a company's constitution, were not treated as a living document, as they had to copy the mandatory provisions of Company Law. In a stark contrast, CL 2005 grants tremendous power to the articles of association and allows shareholders to stipulate rules of conduct in the articles by changing the discretionary provisions of the Company Law. For example, under the old law, corporate profits had to be distributed strictly in proportion to the shareholders percentage of capital contribution in the company. The new law now allows shareholders to specify in their articles any manner of profit distribution agreed to by the shareholders. Indeed, '[t]here are virtually no provisions related to management that cannot be altered or expanded in a manner determined by the shareholders in their articles of association'.121 Further, under CL 1993, a company's external investment in other companies could not exceed 50 percent of the company's net assets. The new law eliminates this restriction by allowing companies to freely invest in other enterprises, provided it does not act as a contributor that assumes joint and several liability for the debts of the investee.

\section{Corporate governance and minority shareholder protection: from indifference to activism}

Revolutionary changes were brought by CL 2005 to strengthen corporate governance and shareholders' protection. The most significant and interesting change is the introduction of a framework of management duties resembling common law fiduciary duties, ${ }^{122}$ under which corporate

\footnotetext{
120 Jiang Ping (2006).

121 Dickinson (2007), p. 2.

122 Anderson and Guo (2006a), p. 19.
} 
directors, supervisors, and senior management personnel owe the company a duty of care and a duty of loyalty. A violation of the fiduciary duty might make the aforesaid persons personally liable.

In a stark contrast with the old law, CL 2005 explicitly grants shareholders a great deal of new rights, thus shareholders now have the statutory rights to inspect the company's books and records, to convene a shareholders' meeting themselves if the company's governing institutions fail or are unable to call such a meeting, and to petition the court to revoke an illegal resolution passed by the company's board or shareholders' meeting. Shareholders are also given the option to adopt a cumulative voting system. They are entitled to sell their shares back to the company under certain circumstances, and to invite judicial intervention to liquidate the company if the company has serious operational difficulties.

The most significant development is probably the addition of the statutory right to file derivative lawsuits to defend their and the company's interests. Civil litigation, known as private enforcement by the shareholders, enables the shareholders to sue the wrongdoer before a court of law to seek damages. Private enforcement seems apparently to be a form of legal remedy that is more consistent with the concept of distributive justice as it helps the shareholders whose interests are harmed to recover their losses. More importantly, private enforcement provides a more effective deterrent to violations of minority shareholders' rights. Minority shareholders suffering damage, with the assistance of lawyers, are more motivated and effective than anyone else to enforce their rights that cannot be enforced through ordinary corporate law mechanisms, such as removing management.

The legal provisions concerning private enforcement contained in the 1993 Company Law (the Old Company Law) were vague and rudimentary, and for all intents and purposes unenforceable. The shift of the focus of shareholder protection from public enforcement to private enforcement represents arguably the single most important rule of law development in China's corporate law system. Judicial protection would enable minority shareholders to monitor the management in a more efficient way and ensure more careful and faithful corporate decisions. Compared with the old law, the new rules are clearer, more practical, and more enforceable, and thus more likely to bring about effective and just settlement of corporate legal disputes. 


\section{Creditor protection: from absolute limited liability to 'piercing the corporate veil'}

Under the old Company Law shareholders are always sheltered by the statutory limited liability, leaving creditors virtually no legal recourse if the shareholders use the company as a sham to defraud them. CL 2005 introduces new doctrines of 'abuse of shareholder rights' and 'piercing the corporate veil'. Shareholders are prohibited from abusing the independent legal person status of the company or their own limited liability privilege; otherwise, the creditors may catch the personal assets of the shareholders for the repayment of company debts.

\subsection{COMPANY LAW IN THE CONTEXT OF CHINA'S POLITICAL, SOCIAL, AND LEGAL CULTURE}

In understanding China's Company Law one must also understand the unique political-legal environment in China. In China's one-party political system, the ruling party has the basic instinct to put everything, including business corporations, under its political control, although in the reform era the party has long realized that independent commercial enterprises are the key to achieving economic growth and for this it has returned autonomy to enterprises through the implementation of a variety of civil and commercial laws. Furthermore, the socialist nature of the political-legal system also requires business firms to sacrifice a certain degree of freedom of enterprise to cope with the state's official ideology and the regulators' policy agendas. In summary, as one commentator advises, "[f]oreign investors who wish to set up enterprises in China should take note of [the uniquely Chinese definition of the business corporation as a hybrid economic-political-sociocultural institution] and be prepared to interact closely with the CCP and other governmentaffiliated organizations, and to provide their willingness to comply with the official interpretation of corporate social responsibility'. ${ }^{123}$

\subsubsection{Organization of the Chinese Communist Party in Companies}

An often-ignored provision in the Company Law is Article 19, which states, 'an organization of the Communist Party of China (CPC) shall be established in a company to carry out party activities according to the Charter of the Communist Party of China' and mandates the company to

123 Hawes (2007), p. 823. 
'provide necessary conditions for the activities of the [CPC organization]'. An annotation of the Company Law published by the Legislative Affairs Commission of the National People's Congress interprets Article 19 as follows: ${ }^{124}$

According to our country's Constitution, the basic task of the nation is to concentrate its effort on socialist modernization along the road of building socialism with Chinese characteristics. The Chinese people of all ethnic groups will continue to be under the leadership of the Communist Party of China to construct our country and turn it into a socialist country that is prosperous, powerful, democratic and culturally advanced. The provision of the constitution explicitly points out the leadership position of the CPC in our country's political life and economic construction. In order to better strengthen the role of the CPC grassroots organizations and CPC members in the company's development and economic construction, this Law makes specific provisions in regards to the activities of CPC grassroots organizations according to the Constitution. The provision has a two-prong meaning. First, the CPC Charter should be obeyed to establish the CPC organization and carry out Party activities in a company. Under the CPC Charter, a grassroots Party organization should be established in an enterprise, village, governmental agency, school, science research institution, residential district, military company or other grassroots unit if the aforesaid unit has more than three official members of the Party. The CPC's grassroots organization should carry out its activities according to the CPC Charter. Secondly, the company should give support, such as providing the necessary venue, to the CPC organization's activities.

Article 19 begs the question about what the party organizations do in business firms. According to the CPC Charter, 125

In a state-owned or collective enterprise, the primary Party organization acts as the political nucleus and works for the operation of the enterprise. The primary Party organization guarantees and supervises the implementation of the principles and policies of the Party and the state in its own enterprise and backs the meeting of shareholders, board of directors, board of supervisors and managers (or factory director) in the exercise of their functions and powers according to law. It relies wholeheartedly on the workers and office staff, supports the work of the congresses of representatives of workers and office staff and participates in making final decisions on major questions in the enterprise. It works to improve its own organization, provides leadership over trade unions, the Communist Youth League organization and other mass

\footnotetext{
124 An Jian (2005), p. 41.

125 Charter of the Communist Party of China, Article 32, quoted in Hawes (2007), p. 818.
} 
organizations, and carries out ideological and political work, and cultural and ethical improvement programs.

In a non-public economic institution, the primary Party organization carries out the Party's principles and policies, provides guidance to and supervises the enterprise in observing the laws and regulations of the state, exercises leadership over the trade union, the Communist Youth League organization and other mass organizations, rallies the workers and office staff around it, safeguards the legitimate rights and interests of all stakeholders, and stimulates the healthy development of the enterprise.

At this stage, there are no fundamental contradictions between the CPC's disciplines and the companies' business objectives, as the party-state's self-imposed task is to achieve economic development. In fact, party members in business enterprises are required to help the firms grow their revenue and profit. ${ }^{126}$ However, since CPC members are obligated under the CPC Charter to implement party policies and put 'the interests of the Party and the people above everything', ${ }^{127}$ uncertainty remains as to what will happen if party policies and interests change. Further, notwithstanding the NPC Legislative Commission's enthusiastic 'justification' above, the constitutionality of Article 19 is questionable from the perspective of legal positivism. In essence, there might be no constitutional basis for granting such a privileged position to the CPC. Under the PRC Constitution, no individual or organization, including any political party and its members, is above the law. The Constitution does not offer such special rights to CPC organizations and members that they can enjoy such free 'tribute' offered by any enterprise more than three of whose employees are CCP members. As such, Article 18, if enforced, effectively constitutes an unconstitutional expropriation of (private) corporate property without fair compensation. If the company is privately owned, Article 18 provides a basis for the CPC's unconstitutional infringement of private property; if the company is an SOE, Article 18 is accordingly an infringement of the SOE's 'corporate property rights' and also undermines its autonomy as an independent legal person.

\subsubsection{Trade Union, Labor Rights, and 'Democratic Management'}

The protection of company employees' rights traditionally does not fall within the jurisdiction of corporate law, and hence it will not be

126 Hawes (2007), p. 819 (quoting a party member working at Wal-Mart as saying that 'one of the criteria for evaluating Party members' progress is whether we have helped to increase sales at the Wal-Mart stores where we work').

127 Charter of the Communist Party of China, Article 3. 
discussed in detail in this book. It is, however, worth noting that the PRC Company Law has two very interesting provisions, namely Articles 17 and 18, which govern labor rights and labor organizations in companies. Article 17 mandates that a company should protect the lawful rights of its staff and workers, sign labor contracts with them, and provide social security insurance and labor protection. Article 18, a provision for trade union and workers' 'democratic management', reads:

The employees of companies may organize trade union[s] and carry out union activities in accordance with the Trade Union Law of the People's Republic of China to protect the lawful rights and interests of the employees. The company should provide the requisite conditions for the activities of the trade union. The trade union shall sign collective contracts on behalf of the employees with the company on matters such as wages, working hours, welfare, insurance, work safety and health etc according to law.

Under China's 1992 Trade Union Law (amended in 2001), there is only one trade union lawfully allowed in China, which is the All-China Federation of Trade Unions (ACFTU). ${ }^{128}$ Under the ACFTU are different levels of trade union organizations. It further requires that a basic-level trade union organization be set up in an enterprise, an institution or a government agency with a membership of 25 or more. ${ }^{129}$ However, a trade union organization is not permitted to be established on the initiative of the workers. The Trade Union Law mandates that the establishment of a union at a particular level should be submitted to the union organization at the next higher level - and ultimately the ACFTU - for approval. Obviously enough, the trade union is a tool to strengthen the CPC's political control of workers' activities in Chinese enterprises. It is, however, important to note that this kind of control is not necessarily for interfering with the enterprise's business management. It is more of a tool for social control, in order to prevent workers from being organized by forces outside the Chinese government. ${ }^{130}$

128 Article 2, para. 2 of the PRC Trade Union Law states: 'The All-China Federation of Trade Unions and all trade union organizations under it represent the interests of the workers and staff members and safeguard the legitimate rights and interests of the workers and staff members according to law'.

129 PRC Trade Union Law, Article 10.

130 On 29 July 2006, Wal-Mart, which was infamous for its anti-union stance, witnessed the first trade union established by its China workers at its store in Quanzhou City, Fujian Province of China. In about two weeks, 19 Wal-Mart stores in China established trade unions. Outside China, Wal-Mart permitted the operation of unions in only one of its stores, in Canada. However, the pressure to 


\subsubsection{Corporate Social Responsibility}

Corporate social responsibility (CSR) has emerged as an issue of increasing social and business importance in corporate China. The concept of CSR was invented in the West long before China arose as a central part of the global production network. ${ }^{131}$ In recent years, CSR has caught considerable attention in China, leading to an emerging normative framework. The Company Law has a specific provision on CSR. Article 5 of the law stipulates: 'When engaging in business activities, a company must abide by laws and administrative regulations, observe social morals and business ethics, act in good faith, accept supervision by the government and the public, and bear social responsibilities'. On 27 September 2006, the Shenzhen Stock Exchange issued the 'Social Responsibility Instructions to Listed Companies', which defines CSR as 'the obligations listed companies should assume for the comprehensive development of the nation and the society, for natural environment and resources, and for stakeholders including the shareholders, creditors, employees, customers, consumers, suppliers and communities'. ${ }^{132}$

A more recent initiative by the government is the promulgation of the Guiding Opinions on Practicing Social Responsibility by Central Enterprises by the SASAC (hereinafter the 'CSR Opinions'), 133 in which the SASAC ordered China's centrally administered SOEs to play a leading role in CSR. It provides a broad definition of CSR that covers environmental protection, energy and resources conservation, work safety, labor protection, consumer rights, maintaining market order, upholding business ethics and philanthropy, shareholder value, and job creation. Apparently, these are often mutually conflicting objectives that are difficult to implement by one enterprise.

approve the establishment of trade unions was not from the desire of workers. Instead, Wal-Mart received direct state influence through the ACFTU, which has launched an aggressive campaign to set up branches in all foreign-invested companies. The decision to allow China trade unions was a result of direct negations between Wal-Mart and the ACFTU. See BBC, "Chinese "create Wal-Mart union"”, 31 July 2006, available at http://news.bbc.co.uk/2/hi/business/ 5230378.stm (accessed 13 March 2012).

131 Jensen (2006).

132 Shenzhen Zhengquan Jiaoyisuo Shangshi Gongsi Shehui Zeren Zhiyin [Shenzhen Stock Exchange Social Responsibility Instructions to Listed Companies], promulgated on 25 September 2006, available at http://www.szse.cn (accessed 2 August 2007) (hereinafter the SZSE CSR Instructions).

133 Guanyu Zhongyang Qiye Luxing Shehui Zeren De Zhidao Yijian, SASAC Doc. No. 1 of 2008, 4 January 2008. 
At the industry level, the China National Textile and Apparel Council (CNTAC) was the first among industry associations to launch a programme pushing for CSR. It held the first industry-wide annual conference for CSR in December 2006 and issued the first Annual CSR Report for China's Textile and Apparel Industry. ${ }^{134}$ In May 2007, CNTAC, joined by the International Labour Organization (ILO) and United Nations Industry Development Organization (UNIDO), launched the Joint Project on Corporate Social Responsibility in the Chinese Textile Industry. ${ }^{135}$ It purports to develop training programmes and toolkits based on the ILO's Factory Improvement Programme (FIP), UNIDO's Cleaner Production Programme (CP) and Responsible Entrepreneurs Achievement Programme (REAP), as well as the CNTAC's CSC9000T. Sinochem, one of the largest SOEs in China, was one of the first Chinese companies to release a CSR report on 13 April 2007. ${ }^{136}$ Foreign-invested enterprises (FIEs) moved even faster: on 27 March 2006, 69 FIEs, with the endorsement of the PRC Ministry of Commerce, signed a Corporate Social Responsibility Beijing Declaration. ${ }^{137}$

The CSR movement in China appears to be a top-down process at this stage. At first, it was a response of the business community to a call from the central leadership, in particular President Hu Jintao, to adopt a new approach to the project called the 'scientific development concept', and to build a 'harmonious society' in China. ${ }^{138}$ In fact, all the above CSR

134 'To Build a Responsible Supply Chain by Putting CSR Management into Practice - Annual Conference on CSR for China's Textile and Apparel Industry and Its Annual CSR Report Release', 12 December 2006, available at http:// www.csc9000.org.cn (accessed 2 August 2007).

135 'Opening Ceremony of the Joint Project (ILO/UNIDO/CNTAC) on Corporate Social Responsibility in the Chinese Textile Industry', available at http://www.csc9000.org.cn (accessed 2 August 2007).

136 'Sinochem Releases Its First CSR Report', Xinhua News Agency, 18 April 2007, available at http://news.xinhuanet.com/fortune/2007-04/18/centent_ 5992203.htm (accessed 2 August 2007).

137 'Promoting CSR for a Harmonious Society - Press Conference for the Beijing Declaration on CSR' 28 March 2007, available at http://caefi.mofcom. gov.cn/article/cz/huiyuan/200603/20060301767990.html (accessed 2 August 2007).

138 Fewsmith (2004), and Miller (2006). The concept of 'Socialist Harmonious Society' is seen as an effort of President Hu Jintao to install a new type of ideology, emphasizing harmonious relationships among social players, into Chinese society, presumably as a replacement for the traditional 'class struggle' theory of the CCP. Although a definition of 'harmonious society' has not yet been given, it seems to ask for social tolerance and caring for the interests of others. 
initiatives refer to the concept of 'harmonious society' as a justification for their 'good deeds'. ${ }^{139}$ It is also a response of China's export industries, especially the textile and apparel industry, to 'sharp foreign criticism about conditions in [China's] factories amid claims that its cheap exports come at the expense of the environment and workers' safety and pay'. ${ }^{140}$

In spite of Article 5 of the PRC Company Law, it is still an open question whether CSR should be a concern for company law. As Henry Manne remarks, "[t]he illusion of great and threatening power, the superficial attractiveness of the notion, and the frequent repetition of the mantra of corporate social responsibility have made this fallacy a part of the modern corporate zeitgeist'. ${ }^{141}$ Even though CSR should be pursued by companies, it imposes moral rather than legal obligations on corporate behavior. In brief, it is submitted that Chinese company laws should not even consider codifying and enforcing CSR.

139 For instance, Article 1 of the SZSE CSR Instructions: 'These Instructions have been formulated in accordance with the Company Law, the Securities Law and other laws, administrative regulations and the rules of competent authorities for the purpose of implementing the scientific development concept, building a harmonious society, accelerating sustainable economic and social development and promoting commitment to social responsibilities'. SZSE CSR Instructions, supra note 118 .

140 Richard McGregor, 'China's good corporate citizens find their voice', Financial Times, 27 February 2007, at http://www.ft.com.

141 Manne (2006). 